\title{
INDONESIA IN TOBACCO CONTROL EFFORTS TO ACHIEVE SUSTAINABLE DEVELOPMENT GOALS TARGET 3.A
}

\author{
Gatari Dwi Hapsari \\ UPN Veteran Jakarta, Indonesia \\ gatarigunawan@gmail.com
}

\begin{abstract}
This paper entitled Indonesia's effort in Tobacco Control to achieve 3.a targets of Sustainable Development Goals in 2017-2019, which is strengthen implementation of FCTC in all countries, as appropriate. This study is a fascinating case to research due to the growing prevalence of child smokers in Indonesia every year. The damage caused by this problem is multi-dimensional, which includes damage to the economy, economy, and social, even threatening the narration of the Indonesia Golden Era of 2045. This study supported by a sustainable development concept, nonmilitary threat concepts, also public policy to divide the research title.
\end{abstract}

Keywords: Indonesia, smoker prevalence, sustainable development goals, tobacco control.

DOI: $10.33541 /$ sp.v20i1.1470

Sociae Polites : Majalah IImiah Sosial Politik

Faculty of Social and Political Science, Universitas Kristen Indonesia

ISSN 1410-3745 print/ ISSN 2620-4975 online

Volume 20, Number 1 (January - June 2019)

Pages 58-80 


\section{Introduction}

In this current time, Indonesia is a paradise for the tobacco industry (CISDI, 2018). Cigarette production in Indonesia reaches hundreds of billions of cigarettes, making it the country with the most cigarette production in Southeast Asia. The total cigarette production as of April 2019 recorded by the excise authority is one hundred ten point seventy-six billion cigarettes. Indonesia is also the sixth-largest tobaccoproducing country in the World, after China, Brazil, India, the United States, and Malawi. In 2018, Indonesia recorded to produce around one hundred thirty-six thousand tons of cigarettes or approximately $1.91 \%$ of the total world Tobacco Production.

There are at least four cigarette industries in Indonesia that produce large amounts of cigarettes, namely; (1) PT. Djarum, owned by Budi and Bambang Hartono; (2) HM Sampoerna, which was acquired by Philip Morris International (Multinational Cigarette Industry) in 2005; (3) PT. Gudang Garam, owned by Surya Wonowidjojo; and (4) PT. Bentoel International Investama, which was acquired by British American Tobacco in 1990.

A large amount of cigarette production is in line with market demand, which is a large number of goods demanded at a particular market with a specific price level at a certain income level and in a certain period (Putong 2002). The number of active smokers in Indonesia reached 90 million in 2016 (BPPK RI Ministry of Health 2018) and is increasing every year. The need for smokers plus addicted addiction generates a unique demand for cigarette production in Indonesia. This fact is increasingly supporting Indonesia to become a large producer of tobacco products as well as the largest cigarette consumer in Southeast Asia.

But in reality, behind the large production and consumption of cigarettes in Indonesia, there are many problems caused. Exposure to cigarette smoke increases the risk of non-communicable diseases that take the most lives-starting from heart disease, cancer, respiratory problems, pregnancy disorders, factors driving young deaths and illnesses due to other unhealthy lifestyles (The Tobacco Atlas 2015). Also, deaths caused by cigarette consumption were recorded at six million people per year for Tobacco-Related disease, with 600 thousand passive smokers dying from exposure to cigarette smoke.

According to the results of the Basic Health Research (Riskesdas) 2018, the Number of Smokers of Children aged 10-18 years rose to $9.1 \%$, which previously in 2016 was $7.2 \%$. This amount is equivalent to +7.7 million children who start smoking every year (BPPK RI Ministry of Health, 2018). Ages 10 to 18 years old mean children from elementary to high school level.

At present, one of Indonesia's efforts to prevent tobacco-related diseases preventive is through the imposition of excise on tobacco products. Based on the Ministry of Finance data, cigarette excise tax revenue from the tobacco products industry reached Rp 153 trillion in 2018, an increase from 2017 of Rp 147 trillion. Of the cigarette excise tax, it contributed to the acquisition of 95.8 percent of the national burden. Cigarettes themselves are the most significant contributor to the country excise tax revenue, far above the excise tax revenue from alcoholic beverages, pure alcohol, and electronic cigarettes. This is in line with the increasing prevalence of child smokers so that more and more cigarette consumers and automatically increase state revenue from the cigarette excise tax. 
Whereas in the regional government, some city and district governments have made Regional Regulations on No-Smoking Zones, which include a series of rules regarding smoking bans in public areas as well as bans on advertising, promoting, and accepting sponsors from the cigarette industry. But unfortunately, the implementation has not been maximized so that advertisements, promotions, and sponsors are still easy to find. In the long run, exposure to cigarette advertisements and environments with a high number of smokers in adolescents from an early age lead to positive perceptions of smoking activity. In the long run, this naturally leads to the assumption that smoking is a standard product, or commonly known as the normalization of tobacco products.

Normalization of tobacco products in an extended range of time can threaten the condition of the Indonesian population, especially the younger generation. At present, the world of health has categorized tobacco as a cause of catastrophic disease or better known as the tobacco pandemic. The term pandemic itself refers to the condition of a community affected by the disease within a specified period (Noya 2018). Tobacco pandemic is a variety of infections caused by tobacco consumption by burning or commonly known as smoking. This disease is categorized as a pandemic because the tobacco pandemic is a threat to the younger generation in terms of health, socioeconomic, environmental to personal psychological conditions, both as a significant consumer or active smoker or as a secondhand smoker or thirdhand smoker

Along with these problems, Indonesia continues to make efforts to prevent and cope with the tobacco pandemic and various health problems that pose a national threat to Indonesia. Two decades ago, precisely in 1999, several developing countries, namely Indonesia, Latin America, India, and Thailand, initiated a framework that regulates tobacco control efforts comprehensively. Because cigarette consumption has become a global problem and if not addressed, 1 billion of the world's population will die in 2030, with $70 \%$ of them happening in developing countries (WHO 2008). This effort was welcomed by the World Health Organization so well that the Framework Convention on Tobacco Control was officially adopted by the WHO in Geneva, Switzerland, on May 21, 2003. It is unfortunate that, after a long international ratification process, Indonesia canceled ratifying the FCTC. Until now, Indonesia is 1 of 9 countries in the world that have not confirmed this convention together with Andore, Eritrea, Lichtenstein, Malawi, Monaco, Somalia, the Dominican Republic, and South Sudan.

At the same time, there is an international instrument that is very focused on sustainable development, which also considers the health and safety aspects of every human being. The instrument is called Sustainable Development Goals (SDGs). Indonesia is one of 193 countries that have signed a commitment to realize the Sustainable Development Goals (SDGs) that ratified through Presidential Regulation number 59 of 2017. The SDGs are a long-term global plan, consisting of 17 goals and 169 targets, which will be a reference for world development for the next 15 years. The 15 year period shows that the SDGs prioritize a long-term and sustainable approach to development, emphasizing various issues that will always be the needs of the people wherever their country. This long-term development approach reflected in many targets related to the welfare of children and the protection of their future.

As a global plan with a vision of the future, it is very logical to link tobacco control for young people with 17 SDG goals. The relevance of each goal to tobacco control is not only focused on the third goal of health, but also other objectives. This close relationship shows that youth become a chain that can link all development goals and its central position to all human development efforts. The invalid source specified. 
When examined more deeply by starting with several objectives that have a direct link to health, it is clear that the SDGs have opened an ample space for the prevention of chronic diseases. Where in SDG's includes tobacco control. In the third goal of the SDGs on health, it stated, "Ensuring a healthy life and promoting well-being for all."

In goal number three, one of the targets is target number 3.a, namely, Strengthen Implementation of the Framework Convention on Tobacco Control in all countries as appropriate (Strengthening the implementation of FCTC in all countries as a whole). The Invalid source specified Tobacco Control Framework or FCTC. It is a binding agreement that aims to "protect present and future generations from damage to health, social, environmental, and economic consequences due to tobacco consumption and exposure to cigarette smoke." Because, Indonesia as a country that has ratified the SDG's, strengthening the implementation of FCTC as a target of SDG's does not ratify and absorbed intLawublic law in Indonesia. The application of the FCTC is an indicator of the country's efforts to realize the third goal of sustainable development. This certainly has more or less affected the attempts to control tobacco in Indonesia.

In line with the SDGs, tobacco control efforts generally realized through accession to the FCTC and absorption of the framework into the domestic constitution. The case in Indonesia, the state has not yet accessed and ratified the FCTC. The Director of Food and Tobacco of the Ministry of Industry of the Republic of Indonesia, Enny Ratnaningtyas, in a press release stated that the rules in the FCTC were feared to be stricter and prone to the initiator's compulsion to follow foreign interests. In addition to the Indonesian Ministry of Industry, the Ministry of Agriculture also rejected the ratification of the FCTC instrument because it feared that it would harm tobacco farmers (Khamdi, 2013). So that tobacco control efforts in Indonesia are carried out under the mandate of Government Regulation No. 109 concerning Safeguarding Materials containing addictive substances in the form of tobacco products for health.

This raises various problems because of the unbalance of tobacco control and sustainable development policies in Indonesia, one of which mentioned at the beginning of this background, which is an increase in the prevalence of child smokers. In its implementation in Indonesia, the SDG points absorbed into the 2015-2019 National Medium-Term Development Plan (RPJMN). One of the points that were adapted was by targeting a reduction in the prevalence of child smokers in 2019. In the National Development Target (SPPN) precisely the Health Table in the increasing control of infectious and non-communicable diseases, there is a target that is the percentage of smokers aged $<18$ years where at 2013 by $7.2 \%$ is targeted to decrease to $5.4 \%$ in 2019 (Bappenas RI, 2015).

The inclusion of targets in the RPJMN means the government is paying more attention to the problem of child smokers in Indonesia. The problem is that the goal initially expected to fall to $5.4 \%$ of children in 2019, increased in 2018 to $9.1 \%$ of child smokers. This data shows that the target of reducing the number of child smokers fails to be realized by the government. Various factors are underlying this problem. From the asynchronous opinion of the technical ministry regarding tobacco control, the intervention of the tobacco industry in national policies, to the absence of a comprehensive tobacco control policy in Indonesia, which ultimately leads to even more significant problems, namely the threat to sustainable development efforts in Indonesia.

From this problem, the writer is interested to know more about the efforts that have been made both by the Government of Indonesia as practitioners and the United 
Nations Development Program (UNDP) as the responsible SDG's related to achieving targets. 3.a Strengthening the overall implementation of WHO-FCTC in all countries in Indonesia.

\subsection{Research Question}

As an international instrument that provides an opportunity for each country to implement it following their respective capacities, SDG's is the most appropriate approach to bridge tobacco control efforts in Indonesia. Especially with the inclusion of tobacco control indicators in goal number 3, Good Health, and Well Being. Therefore, the authors determine the formulation of the problem in this study is "How is the efforts of Tobacco Control in Indonesia in achieving the target of 3.a Sustainable Development Goals in 2017-2019?".

\subsection{Purposes and Objectives}

Following the formulation of the problem above, the authors set several objectives of this study namely; (1) provides an explanation of the efforts to control tobacco as well as Indonesia's efforts to control smoking, (2) provides a description of the Sustainable Development Goals, specifically target 3.a and its implementation in Indonesia in the 2017 to 2019 timeframe.

\section{Literature Review}

\subsection{Sustainable Development}

Sustainable development formulated as a development activity that meets the needs of the present without compromising the right to meet the needs of future generations. In the concept of sustainable development, the present age is not the owner of the existing natural resources. The current generation is analogous to borrowing natural resources from future generations, so he must maintain and return these natural resources to future generations.

Sustainable development implies a guarantee of the quality of human life and does not exceed the ability of ecosystems to support it. Thus the notion of sustainable development is a development to meet the needs of the present without reducing the ability of future generations to meet their needs. Historically, there was a thought in the late 60s when the natural resource exploitation and exploration intensified that the current development needs to consider future needs. So, not only focus on the present but consider aspects in the future. Currently, the concept of Sustainable Development has been translated into SDG's by having three necessary components, namely (1) Economy, (2) Social and (3) Environment (Sorikmas Mining, 2012) 
Figure 1. Sustainable Development

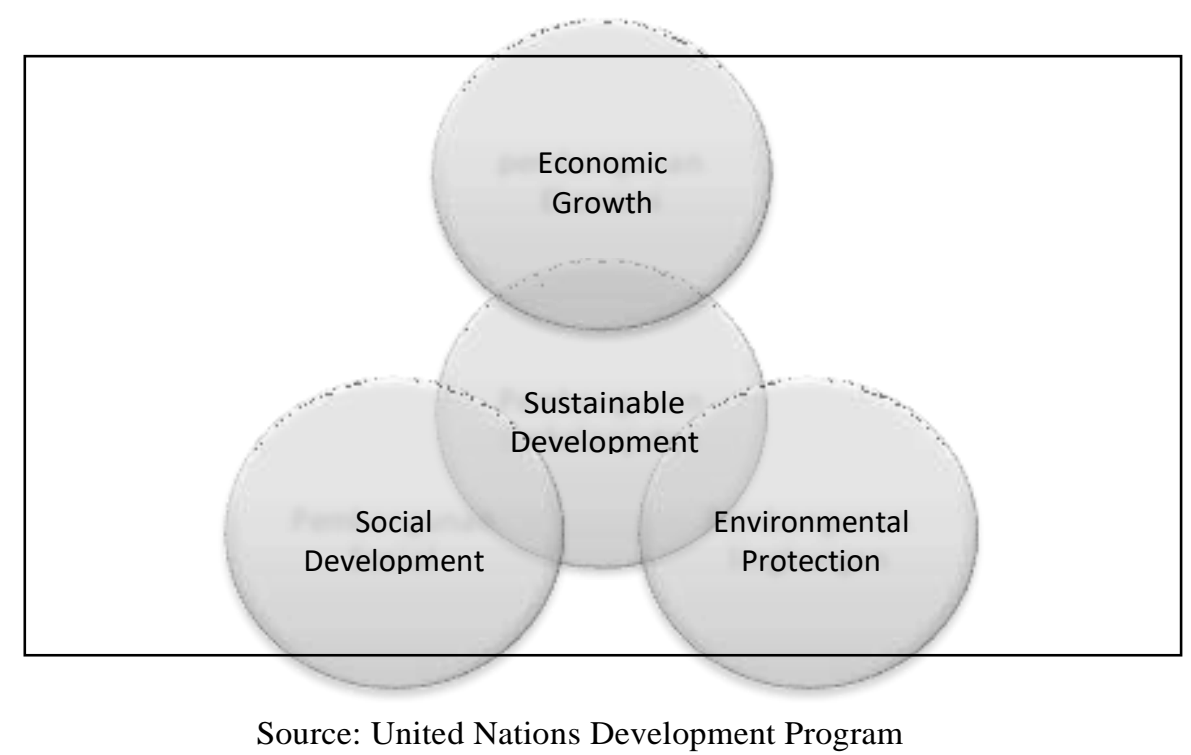

In line with this concept, Sustainable Development was also described by Tomislav Klarin as three balanced development concepts. In its implementation, it is certainly not easy, because each pillar construction must not hamper the manufacture of other pillars, such as economic development, cannot hamper social growth and prevent imbalances in development.

In classical theory, development is usually interpreted together with the framework of development and economic growth. But now, sustainable development takes into account the balance of three basic concepts to meet current needs without reducing the needs of future generations.

From the perspective of International Relations, the concept of sustainable development itself cannot be categorized as a direct derivative of the branch of international relations because sustainable development consists of various scientific disciplines, a complex and systematic discussion. Each country may have different interpretations of sustainable development, depending on the issue of the country's priorities and interests.

The concept of Sustainable Development is now better known as the Sustainable Development Goals (SDGs), which was initiated by the United Nations. As explained in the previous chapter, SDG's is a long-term global plan, consisting of 17 goals and 169 targets that will be a reference for world development for the next 15 years. The 15 year period shows that the SDGs prioritize a long-term and sustainable approach to development, emphasizing various issues that will always be the needs of the people wherever their country. This long-term development approach reflected in many targets related to the welfare of children and the protection of the future.

Indonesia itself has ratified the SDG through Presidential Regulation No. 59 of 2017 regarding the implementation of the Sustainable Development Goals. This means all Goals and Targets in SDG's has officially become a commitment that must be achieved by Indonesia. Indonesia's commitment scheme in realizing sustainable development begins with the National Action Plan (RAN), incorporating development 
targets in the National Medium-Term Development Plan (RPJMN) and Strategic Plan (Renstra).

On SDG's Goals 3, namely Health and Well-Being, one of the targets that countries need to undertake to meet the achievements of sustainable development is Target 3.a, Strengthen the Implementation of the WHO-FCTC in all states, as appropriate. This target is more focused on implementing FCTC or a comprehensive tobacco control framework. In 2007, WHO itself practically introduced effective ways for countries to implement the WHO-FCTC through the MPOWER formula. MPOWER is easy steps in carrying out the scope of the contents of the FCTC convention, which consists of:

\section{Table 1. EMPOWER Key WHO-FCTC}

\begin{tabular}{|ll|}
\hline 1. & Monitor tobacco use and prevention policies \\
2. & Protect people from tobaccouse \\
3. & Offer help to tobaccouse \\
4. & Warn about the dangers of tobacco \\
5. & Enforce bans on tobacco advertising, promotion, and \\
& sponsorship
\end{tabular}

Sumber: World Health Organization International

WHO has introduced the country that to implement FCTC, six things need special attention for the country, namely; (1) Monitoring the use of tobacco products and prevention policies, so that the efforts made are complete both upstream as preventive and downstream as repressive; (2) Protection from tobacco use, in this case, protection for passive smokers from cigarette smoke; (3) Smoking cessation assistance/services, which are provided by certified therapists in hospitals, clinics, and other health facilities; (4) Warning of the dangers of tobacco use, such as Pictorial Health-warning, plain packaging display and so on; (5) integrated prohibition of advertising, promotion, and sponsorship from the cigarette industry; (6) increase cigarette excise as high as possible to control its consumption.

In addition to the MPOWER formula introduced by WHO, the Framework Convention Alliance - NGO in the field of advocacy for sustainable development - has also issued a toolkit for countries that wish to ratify / access FCTC. The kit is titled "HOW TO TAKE" FCTC IMPLEMENTATION "FROM THE SUSTAINABLE DEVELOPMENT GOALS (SDGS) AND TRANSLATE IT INTO ACTION IN COUNTRY," in which various explanations and concrete steps needed for countries to implement the points in the FCTC.

\subsection{Non-military Threat}

The National Threat now does not only come from the military realm that uses weapons and organized. At present various national security threats arise from the nonmilitary dimension. Non-military risks are mostly threats that use non-military factors considered to have abilities that jeopardize the country's sovereignty, the territorial integrity of the country, and the safety of the whole nation. Non-military threats can 
have ideological, political, economic, socio-cultural, technological and information dimensions, and public safety (Jerry, 215: 69).

Meanwhile, the Defense Ministry's non-military threats are threats faced daily by the nations of the world today, such as threats that can damage the nation's noble values, namely radicalism, terrorism, drugs, climate change, natural disasters, resources nature and so on. This has become a world trend that non-military threats are threats that must be addressed by all elements of government (Kemhan, 2017). Non-Traditional Threats can also take the form of an outbreak that attacks the health of the population massively. In this case, like the Tobacco Pandemic, which takes hundreds of thousands of Indonesians every year, also categorized as a Non-Traditional Threat. This threat needs to be addressed thoroughly by the relevant ministries and technical institutions and requires the role of the community to work together.

\subsection{Public Policy}

Public policy is "A purposive course of action followed by an actor or set of actors in dealing with a problem or matter of concern" or a series of actions aimed and carried out and followed by an actor or several actors for a particular problem (Anderson 1984). Anderson's explanation emphasized that the definition of public policy has five kinds of implications. Namely, (1) each system has particular objectives to be achieved. 2) system consists of a series of actions or patterns of actions taken by the government. 3) systems in the form of actions taken by the government and not just about the desire to do something or want to do something. 4) policies can be either positive or negative. And 5) public policy at least in its definite form is Lawed on law and is therefore authoritative. The five implications are interpretations of public administration according to Anderson

Besides Anderson, Public Policy is also defined by Larry N. Gerston in his book Public Policy Making in a Democratic Society: A Gude to chivic Engagement. As a combination of various decisions, commitments, and actions made and implemented by those who hold power in government or influential on the course of government (Gerston 2002).

In Gerston's view, the public policy contains not only a series of decisions but also the commitment and concrete actions of those involved in government. This can get interpreted that those who make decisions must have a strong dedication to the choices they have made, that the decision was made correctly, contains an excellent substance by the interests of the community, and can get implemented in a tangible form towards the desired goal.

Once again, drawn into the case of tobacco control efforts by Indonesia, one of which is the excise policy. The policy gets taken by the government as an active effort to control tobacco consumption and production. To measure the effectiveness of these policies, the author will use the concept of public policy and analyze its implications in the micro-region.

Public policy generally consists of a series of actions, namely planning, law, and behavior adopted by the government. Along with the pattern of "the new government" illustrates that the sequence of activities is more often carried out by the agent of state than carried out by the country itself, as do non-state actors. A large number of studies offer detailed reports on the effects of new public management and the emergence of new governments in specific policy sectors, such as health care, social welfare, police, 
and general security. However, policy analysis often includes prescriptive and descriptive dimensions. Public policy academics strive to find solutions to policy problems and study government responses to them. Of course, their answers are specific proposals aimed at particular policy problems. However, at other times, they are concerned with general questions about how countries should try to implement their policies (Encyclopedia Britannica 2016).

According to Winarno (Winarno 2011), the stages in the policy formulation process:

- Defining Problems

Recognizing and formulating problems is the most fundamental step in policy formulation. To be able to develop policies properly, public issues must get identified and well defined. Public policy exists to resolve the problems that arise in society and are carried out by the government

- Policy Agenda

Not all public issues will be on the policy agenda. To get on the policy agenda, civil matters must meet certain conditions, such as whether the problem has a significant impact on society and requires immediate treatment.

- Selection of Alternative Policies to Solve Problems

After public problems are well defined and policymakers agree to put the issue on the policy agenda, the next step is to make a solution to the problem. Here the politicians will deal with alternative policy choices that can get taken to solve the problem.

- Policy Determination Stage

After one of the many alternative policies decided to get taken as a way to solve the policy problem, the final step in forming the system is to determine the chosen method so that it has binding legal force. The alternative policies taken are a compromise of the various interests involved in the formation. Determination of policies can take the form of laws, jurisprudence, presidential decrees, ministerial decrees, and so forth.

According to Thomas R. Dye in his book Understanding Public Policy (1955), there are at least nine models of policy formulation, namely the system model, the elite model, the institutional model, the group model, the process model, the rational model, the incremental model, the public choice model, and the game theory model. (Agustino 2008). To make a more specific analysis, the authors use the elite model public policy approach to dissect the tobacco excise tax regulation policy.

The Elite model in the public policy approach states that public policy is an abstraction of the interests of the political elite. Systems that use this model tend to lean towards elite interests rather than general needs and demands.

This model also states the existence of groups, where the first group is the elite, or people who have power. The second groups are the masses of people who do not have control. With this elite model, the policy to be issued is the result of the preferences of the elite. From the model, it is roughly like this from the scheme of the process and implementation of public policies in the field of tobacco control. 
Figure 2. Public Policy on Tobacco Tax

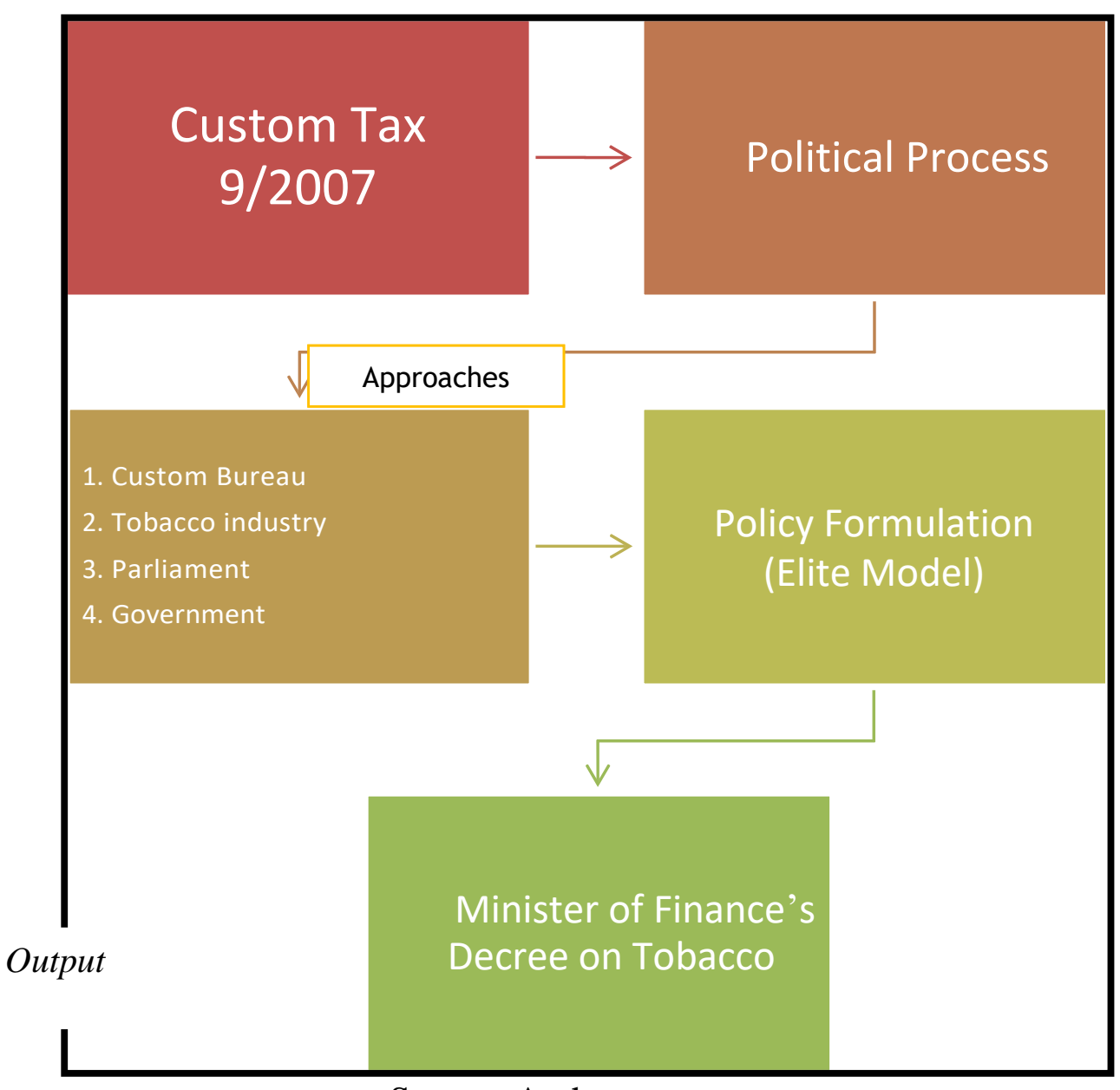

Source: Author

In the concept of public policy, there is a theory that explains how political conditions affect regulation. This term is better known as regulatory politics. According to Mercy DeMenno in his dissertation, The Politics of the policy-making Process: Three Essays on Governments, Markets, and Effective Regulatory Governance is a chain of causality in regulative policy-making. In which there is the involvement of stakeholders and institutional design, the country/form of government (DeMenno, 2018). The author will use the concept of public policy and regulatory politics in translating the efforts currently carried out by Indonesia in tobacco control, especially in analyzing policies issued. Such as tobacco tax and excise regulations, health warning policies illustrated through the minister of health regulation, and local regulations on non-smoking areas

\section{Results and Discussions}

Indonesia began to ratify the SDG's in 2017 through presidential regulation number 59 of 2017 concerning Sustainable Development Goals as consideration of several things. Namely, (1) Indonesia is one of the United Nations members states that plays an active role in setting targets for sustainable development goals, as stated in the 
Transforming Our World: The 2030 Agenda for Sustainable Development. (2) This PP gets endorsed as a commitment of the government in the achievement of the Sustainable Development Goals. Namely that there is a need for violence with the National LongTerm Development Plan and the National Medium-Term Development Plan. These two things are the background of the ratification of presidential regulation number 59 of 2017.

In PP number 59 of 2017, SDG's referred to as the Sustainable Development Goals (TBP) is a document that contains 2016 global goals and objectives until 2030. TBP aims to improve the economic welfare of the community sustainably. Maintain the sustainability of the social life of the city, maintain the quality of the environment inclusive growth and development and implementation of governance that can support the improvement of the quality of life from one generation to the next (Presidential Regulation No. 57 2017).

This policy contains a road map/roadmap that includes the planning of strategic steps that will be undertaken by Indonesia in the achievement of the 2017-2030 TPB by national development goals. The development targets themselves are guidelines for ministries and institutions in developing, implementing, monitoring, and evaluating the National Action Plan by their respective duties and functions. The road map and National Action Plan itself determined by the Minister of National Development Planning or the Head of BAPPENAS.

Bappenas has an essential role in the implementation of TPB in Indonesia. Article 7 of PP 57/2017 states that the head of Bappenas gets tasked with coordinating several things such as; (1) as a facilitator in the preparation of TPB RAD (for the regional realm), (2) monitoring, evaluating and reporting TPB achievements at the national and local level, (3) as well as coordinating TPB funding sources from both the government and other sources (Presidential Regulation No. 57, 2017).

The TBP road map itself in the central domain has the following scheme:

Figures 3. Sustainable Development Goals

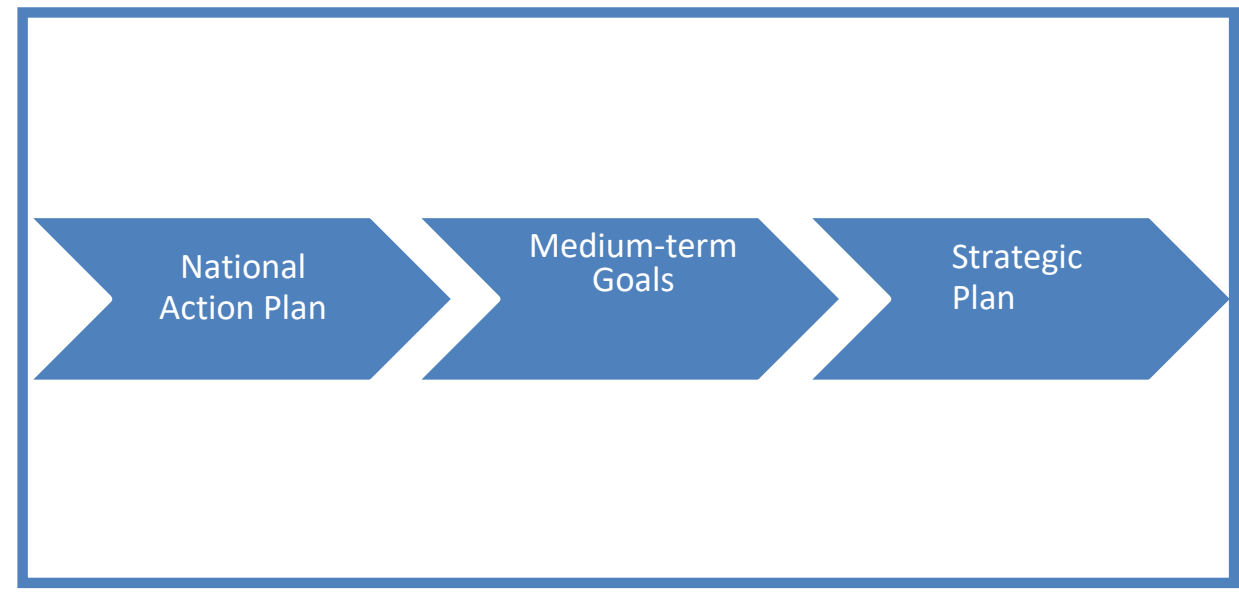

Source :PP 59/2017

The diagram shows that the initial stages of setting sustainable development goals found in the national action plan prepared by Bappenas. Furthermore, this target is 
evaluated and developed through a process called the academic review in which there is input from academics in the form of background studies for later as a guide in the preparation of the relevant ministry and professional agency RPJMN. Afterward, the determination of the strategic plan as the key to implementing things done from the targets set in the RPJMN.

In the case study of tobacco control efforts, as explained in the background section of the study, these efforts have become part of the leading national development targets of the 2015-2019 RPJMN. In the RPJMN National Targets, Bappenas targets to decrease the percentage of smoking in the population aged $\leq 18$ years in 2019 to $5.4 \%$, which previously in 2013 was in the range of $7.2 \%$ of the total children in Indonesia. Unfortunately, this goal does not get achieved by Indonesia. Instead of reducing the number of child smokers, Indonesia increased the number of child smokers to $9.1 \%$ (BPPK of the Indonesian Ministry of Health, 2018). Indonesia's failure to reduce the total of smokers indicates problems with tobacco control efforts to achieve health and well-being for the entire community. In this chapter, the author will discuss specifically how the Government of Indonesia is implementing SDG's implementation, both policy schemes, and application in ministries and technical institutions responsible for the goal of reducing the prevalence of child smokers.

\subsection{Implementation of Target 3.a SDG's in Indonesia}

In the implementation of Target 3.a SDG's in Indonesia, namely, Strengthen implementation of FCTC as appropriate, Indonesia is guided by the National Development Goals (SPPN), specifically the Health Table in the increasing control of infectious and non-communicable diseases. Indonesia has a quantitative target, which is the percentage of age smokers $<18$ years which in 2013 was $7.2 \%$ targeted to decrease to $5.4 \%$ in 2019 (Bappenas RI, 2015). Therefore, as a form of strategic implementation of the target, Indonesia issued several public policies as a basis for the technical implementation of tobacco control in Indonesia.

\section{- Excise}

In a comprehensive tobacco control effort, the instrument for imposing excise duty on tobacco products is one of the essential regulatory policies that the state must carry out. The FCTC advocates that tax and pricing policies on tobacco products to reduce the affordability and consumption of tobacco, especially in certain groups, such as children and low-income families. The FCTC also recommends banning or limiting tax-free sales or imports of tobacco products.

At present, Indonesia imposes a tax levy on every cigarette getting traded. In addition to excise duties, there are also other cigarette taxes, namely local cigarette taxes and value-added taxes. By the mandate of Law number 39 of 2007 article 1 paragraph 1 that what is meant by excise is: "Excise is a state levy imposed on certain goods which have the traits or characteristics stipulated in this law."

The nature or characteristics of excisable goods referred to in the said article, are explained in article 2 paragraph 1 namely; (1) consumption needs to get controlled; (2) its circulation needs to be monitored; (3) their use can harm society or the environment; or (4) its use requires the imposition of state levies for justice and balance. Each year the excise tax rate will be determined through the policy regulation of the finance minister. Since 2015 excise tax rates on tobacco products have increased each year, but 
an anomaly occurred in 2018, where cigarette excise tax rates were not raised. Here the author recognizes political importance in excise tax regulation.

According to the concept of regulatory politics in De Menno's dissertation, public participation in policy-makingicymaking involves two aspects; (1) regulation in the dissemination of information and (2) involvement of stakeholders to proLaws the law into regulative policies (DeMenno, 2018). In the case of excise tariffs, information dissemination gets done through the media, where the media use it as a means to disseminate information. While the stakeholders who play a role in customs tariffs are the directorate general of customs and tobacco industry, The public policy process that occurs at the excise tax rate is the translation of excise law number 9 of 2007 into the Minister of Finance Regulation (Permenkeu). And it is continually getting updated every year. This process involves several actors outside the stakeholders, in this case, public participation. Unfortunately, public participation represented by the voice of the tobacco industry, and this form can get seen through industry intervention in the legislative setting one of which is the Draft Law (Raharjo \& Tanjung, 2019)

Withdrawn from the case study of how the cigarette industry is still involved as an elite group in determining excise tariffs, of course, policies which are outputs of elite interests will tend to benefit certain parties.

The price of expensive cigarettes as a result of the increase in excise tax is, of course, a concern for the cigarette industry to the declining sales figures. Therefore, the tax increase is not significant, and fluctuating provides an opportunity for the industry to produce more cigarettes with a lower tax imposition.

At present, the Excise policy in Indonesia has also not been successful in reducing tobacco consumption effectively. Results of the author's interview with Lara Rizka, MAAPD. The project officer of the Center of Indonesia's Sustainable Development Initiatives (CISDI) states that the following factors cause it.

(1) low and limited excise tax, explanation of article $57 \%$

(2) the tariff increase is determined by the excise tax target not based on a decrease in tobacco consumption. Based on risked, prevalence is still rising and not yet become the main priority factor in implementing excise tax increases

(3) tariff adjustments again take into account the conditions and aspirations of the cigarette industry, cigarette industry meetings. The customs directorate general

(4) the classification of tobacco products is still complicated and has not been simplified. Thus, allowing consumers to switch to cheaper products without having to reduce tobacco consumption.

\section{- Health Warning}

In the WHO-Framework Convention on Tobacco Control, precisely article no. 11, regulates cigarette packaging \& labeling explicitly. The FCTC recommends that at least the packaging and labels on cigarettes pay attention to the following matters;

1. Don't promote tobacco products

2. include health warnings that explain the harmful effects of tobacco use - if in the text, use the primary language.

3. Provide information about relevant constituents and emissions of tobacco products.

The provisions in the FCTC on tobacco product packaging in Indonesia regulated in PP No. 109/2012 and Permenkes No.56 / 2017. In both regulations, 
producers prohibited from including any information or signs that are misleading or words that are promotive and required to include color images and written health warning signs of $40 \%$ of the packaging area. Based on interviews with Lara Rizka from CISDI, currently, there is still a product packaging that includes promotive sentences, because PP 109/2012 legalizes the use of promotive words for products that have received brand certificates (Rizka, 2019)

\section{- No Smoking Area}

No-Smoking Zone is a term for several areas in which there is a prohibition against carrying out smoking activities, sell tobacco products, advertise, sponsor and promote cigarettes and other sets of rules so that the area is called a No-Smoking Zone. One of the achievements of the Ministry of Health in 2018 is the success in achieving the target of increasing the number and realization of KTR in cities/districts throughout Indonesia. The following explanation relates to the efforts made by the Ministry of Health in tobacco control efforts at the city/district level. Table 4.3 Measuring Performance of Non-communicable Disease Activities.

Judging from the tables and reports, the Ministry of Health has succeeded in increasing the number of non-smoking areas realization by $42.4 \%$. Achievement of the percentage of districts/cities that implement the No Smoking Area (KTR) policy of at least $50 \%$ of schools, achieving the expected target (Directorate of P2PTM, 2018). The figure of $44.2 \%$ is obtained through the calculation formula as follows:

The target was $40 \%$, the realization was $42.4 \%$ or 218 districts/cities out of 514 districts/cities, resulting in the achievement of 106\%. Until 2018 there were 340 districts/cities $(67.5 \%)$ that had regulations on no-smoking zones, only 200 districts/cities (38.9\%) were in the form of no-smoking zones and 127 regencies/cities (24.7) \%) in the way of Regents or Mayors' regulations. There are still $174(33, \%)$ districts/cities either that do not yet have rules or are still in the form of circulars and decrees.

The diagram above has the following details:

1. Regencies / Cities that implement a No-Smoking Zone (KTR) policy of at least $50 \%$ of schools in districts/cities that have implemented KTR policies that assessed as having performed at least $50 \%$ of KTR in schools/madrasas by the laws and regulations governing Areas without Cigarette.

2. The schools in question are schools and madrassas at the level of elementary school and its equivalent, junior high school and its equivalent, senior high school and its equivalents, both public and private, including boarding schools and boarding schools.

3. The scope of the No Smoking Area (KTR) policy consists of 7 arrangements, including those in the school system that regulated in the No Smoking Area legislation that has implemented enforcement according to the criteria.

\section{- Blocking Adverts and Promotions of cigarettes on the Internet}

Regulations on the prohibition of cigarette advertising, promotion, and sponsorship in Indonesia got regulated in PP 109 of 2012. Cigarette advertising is one of the main factors causing someone to smoke. In 2007, the Faculty of Health Sciences, Muhammadiyah University Prof. DR. Hamka (UHAMKA), conducted a study on the Impact of Cigarette Advertising Exposure and Cigarette Industry-sponsored Activities 
on Cognitive, Affective and Smoking Behavior in Adolescents. The results state that the average teenager starts smoking at the age of 14 years. From the same research, the results also showed that $46.3 \%$ of adolescents thought that cigarette advertisements had a significant influence on smoking. $41.5 \%$ of them felt that involvement in activities sponsored by the tobacco industry had the impact to start smoking. Also, 29\% of teen smokers light their cigarettes when they see cigarette advertisements when they don't inhale tobacco. $8 \%$ of teenage smokers stated that they returned to smoking after quitting because they participated in activities sponsored by the cigarette industry.

In mid-2019, precisely at the beginning of June, the Indonesian Minister of Health, Nila Moeloek, sent a letter to the Indonesian minister of communication and informatics (See Figure 5.5). The letter contained Moeloek's appeal to the MOCIT to block cigarette advertisement internet. Following on the message of the Minister of Health Nila Moeloek about blocking cigarette advertisement internet. The Minister of Communication and Information Rudiantara immediately gave direction to the Directorate General of Informatics Applications to crawl or fill out the contents of cigarette advertisement internet directly.

Figures 5.5 Minister of Health's Letter to Minister of Information

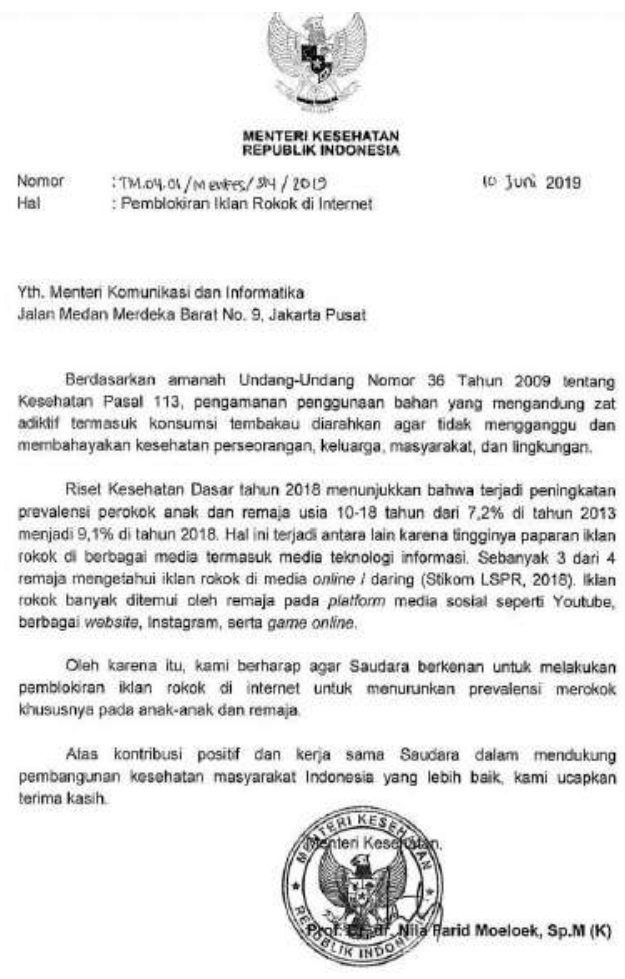

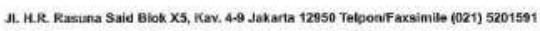

Source: Suara.com

Reporting from Antara news, Ferdinandus Setu, said that the Acting Head of the Public Relations Bureau of the Ministry of Communication and Information explained that the AIS Kemkominfo Team immediately crawled and identified several 114 channels. Both Facebook, Instagram, and YouTube, which violated Law 36 Number 
2009 on health Article 46, paragraph (3) point c concerning the promotion of cigarettes, which shows the form of cigarettes.

From the crawling results, it got found that cigarette promotion content still demonstrates someone who will smoke. The AIS Kemkominfo team is also in the process of taking down accounts or content on several social media platforms. Another follow-up is in the form of a plan for a coordination meeting with Manila Nila. Letter from the Minister of Health of Nila to the Minister of Communication and Information Rudiantara No. TM.04.01 / Menkes / 314/2019 regarding Blocking of Cigarette Ads on the Internet was received by the Ministry of Communication and Information on Thursday, June 13, 2019, at 13.30 WIB. The letter was on June 10, 10 June 2019.

The coordination between the two ministries was a massive success in making cigarette advertisements disappear Internet internet. Especially, cigarette advertisements that break the rules such as showing pictures of cigarettes, showing someone smoking cigarettes, and so forth.

\subsection{Ash area between SDG's and the Government of Indonesia}

Sustainable Development Goals (SDGs) or in Indonesian called the Sustainable Development Goals (TPB) is a continuation of the Millennium Development Goals (MDGs) program that ended in 2015. SDGs contain global development targets or goals that must be achieved in the next 15 years, starting from 2016 to 2030 . The principle of SDGs is "No one left behind" or in Indonesian means that no one is left behind / missed in enjoying development. The targets or objectives in the SDGs serve as guidelines or guidelines for the country's growth to improve the welfare of the global community (PKJS UI, 2019).

SDGs in Indonesia is regulated in Presidential Regulation (Perpres) No. 59 of 2017. The SDGs consist of 17 goals, 169 targets, and 241 targeted indicators that can get achieved in 2030. The 2015-2019 National Medium-Term Development Plan (RPJMN) based on Law no. 17 of 2007 is the third stage of the 2005-2025 National Long-Term Development Plan (RPJPN). The 2015-2019 RPJMN is a guideline for ministries or government institutions in developing, implementing, monitoring, and evaluating development in Indonesia. The vision of the 2015-2019 RPJMN is to realize an Indonesia that is sovereign, independent, and has a personality based on cooperation.

Achieving this vision is done through 7 development missions. The 2015-2019 RPJMN directed to further strengthen holistic development in various fields with emphasizing the achievement of competitive economic competitiveness based on the excellence of natural resources and quality human resources and enhancing the ability of science and technology (Science and Technology). The 2015-2019 RPJMN contains nine priority agendas, which later came to be called NAWA CITA. Six main national development targets consisting of macro objectives, personal and community development goals, leading sector development targets, equity dimension targets, regional and inter-regional development targets, and political, legal, security, and defense targets. Each main objective consists of sub-targets, which then used as indicators of the achievement of SDGs at the national level. Thus, the 2015-2019 RPJMN is closely related to the fundamental basis for achieving SDGs in Indonesia.

This year, the 2015-2019 RPJMN has ended. Therefore, the government is completing the preparation of the 2020-2024 RPJMN as a continuation of the previous RPJMN. Normatively, RPJMN targets should get aligned with SDG targets. Of the 17 
goals, 169 objectives, and 241 indicators listed in the SDGs 2030, the smoking prevalence of people aged $\leq 18$ years and those aged $\geq 15$ years included in signs of achieving the goal of SDGs number 3. In line with SDGs, smoking prevalence in population aged 18 the year is also one indicator in making the 2015-2019 RPJMN.

In other words, the government has committed to reducing the number of cigarette consumption. However, the prevalence of smoking in the adult population is not yet in the indicators of achieving the 2015-2019 RPJMN goals, making it difficult to monitor and achieve tobacco control targets, one of which measured by decreasing the prevalence of adult smoking. This is one of the weaknesses of the 2015-2019 RPJMN, which is not yet fully aligned with important SDG targets, such as reducing the prevalence of adult smoking.

However, some weaknesses can hinder the synchronization of SDGs and RPJMN achievements, namely related to Indonesia's commitment to tobacco control through the ratification of the Framework Convention on Tobacco Control (FCTC). The President, as the highest holder of power in Indonesia, is at the forefront of accelerating the achievement of SDGs and RPJMN. So the President's commitment to the issue of tobacco control is needed one of them by signing the FCTC. At present, the Government of Indonesia is still reluctant to ratify the FCTC, so that the implementation of policies related to tobacco control in Indonesia is not yet reliable. As a result, the decline in the prevalence of smoking in Indonesia is prolonged. The incidence of smoking influences various aspects of life economy Economy, economy, education, environment, and gender equality, where these aspects become essential objectives in the SDGs 2030, RPJMN 2015.

According to the Bappenas SDGs secretariat report, smoking prevalence in Indonesia expected to double by 2030 if tobacco consumption not significantly controlled or this control gets kept as usual. Thus, the vision principle of "No one left behind" will be difficult to achieve if essential issues affecting human development, such as smoking behavior, are not adequately addressed.

On the other hand, the United Nations Development Program, as SDG's stakeholders in the global realm, does not yet have coordination with the central government regarding tobacco control. After interviewing with Mrs. Nova, the directorate of public health and nutrition of the National Development Planning Agency. The authors found the fact that during the SDG's implementation as of 2017, the National Development Planning Agency as the compiler of the RPJMN did not have coordination with UNDP regarding tobacco control efforts, or specifically about how to reduce the prevalence of child smokers effectively. According to the results of the same interview, the informant stated that the government normatively obligated to implement all 17 goals. However, what distinguishes SDG's and MDG's is that SDG's countries can choose their indicators according to the conditions in that country, whereas MDG's aren't so that the state has the authority to Sandra.

The signs created by this country are a unique addition to countries whose indicators do not yet exist in the global indicator template. These indicators were compiled by the SDG's secretariat, which is structurally under the National Development Planning Agency and consists of people with diverse backgrounds, including academics, activists, representatives of the business community, etc. This indicator will later become a reference in assessing whether the goals of the SDGs achieved in a country. Unfortunately, guidance from UNDP in mapping indicators, providing technical advice, and guiding comprehensive tobacco control efforts has not 
yet get carried out. Partnership for the goals is the 17th goal in SDG's that also requires attention. Implementation of SDGs cannot be achieved only by doing it individually as the implementation of the main tasks and functions of the institution.

Interviews with other resource persons, Ms. Theresia Sandra from the Directorate for Prevention and Control of non-communicable diseases, also stated that so far, each ministry has its duties and functions. So that in the implementation of tobacco control still found sectoral ego so that development programs that should be a partnership and coordinated are not optimal (Sandra, 2019). Also, Sandra stated that the health ministry is a technical ministry which is located in the downstream so that it only implements programs related to development, not planning. The authority for planning is entire with Bappenas, but for the implementation and evaluation of programs related to tobacco control, the Ministry of Health has a significant role in this.

From this, the writer sees that there are two main problems in implementing the target achievement 3A SDG. First, there is a significant gap both externally between the central government and UNDP, and secondly, coordination between ministries and institutions, both technical ministries and coordinating ministries. Even if the government wants to make a structured effort and dismiss the ego of each institution in achieving the SDG's goals, of course, the work program implemented will be more focused and not merely carry out the main tasks and functions.

\subsection{The solution offered by SDG's}

On the other hand, by adhering to the goals of the SDGs, the government and policymakers can encourage tobacco control efforts in Indonesia. Because the SDGs are guidelines for the preparation, implementation, monitoring, and evaluation of national development, so that they get expected to facilitate advocacy efforts, especially advocacy in increasing the tariffs cigarette tax. That is, SDGs and tobacco consumption itself affect each other.

Several non-governmental organizations have issued a set of guidelines in achieving SDG. The term is like a guide in the technical implementation of SDG's when it has entered into a strategic plan. For example, the International NGO Forum on Indonesian Development (INFID). In 2016, INFID issued guidelines for local governments (cities and districts) and local stakeholders to absorb SDG into the RPJMD. In general, this guide discusses the relationship of SDG with joy, local government, and the sustainability of the Millennium Development Goals program. While technically, this guide contains technical guidance from the road map for the implementation of the SDGs, how to draw up regional action plans, and who is on the membership of the committee for implementing sustainable development goals in the regions.

In the international realm, several non-governmental organizations issue similar guidelines, one of which is the convention alliance framework. This NGO issued the same guidance titled "HOW TO TAKE" FCTC IMPLEMENTATION "FROM THE SUSTAINABLE DEVELOPMENT GOALS (SDGS) AND TRANSLATE IT INTO ACTION IN-COUNTRY "and is used by several developing countries to implement FCTC into SDG frameworks in their respective countries.

\subsection{Indonesian Tobacco Control Achievement in meeting target 3.a SDG's}


Indonesia already has development priorities by the programs and priorities in the 2015-2019 Mid-Term Development Plan (RPJMN). Referring to this, several things intersect between the SDGs and Nawacita. As is well known, nawacita is a cornerstone of development issued by the administration of President Joko Widodo. In terms of human development and efforts to reduce inequality, the two documents are in harmony. In an economic growth, the two are also mutual friends. However, in terms of sustainability, Nawacita and the RPJMN must make many adjustments.

Nawacita, RPJMN, the National Strategic Plan, is part of an extensive framework that houses tobacco control efforts. During the period 2017 to 2019, tobacco control in Indonesia began to grow and develop better than before. For example, cigarette excise, which regularly rises every year. The increase in prices on cigarettes certainly again aims to protect the public from the effects of cigarette consumption through regulative policies. This will more or less distance the cigarettes from vulnerable groups, such as children and low-income families. Excise tax regulations on cigarette prices make vulnerable groups unable to reach the need for cigarettes and reduce/stop cigarette consumption.

In addition to excise duty, a preventive measure also carried out by the government is to issue a pictorial health warning policy. This policy gets regulated in PP No. 109/2012 on the Elimination of Materials containing addictive substances in the form of tobacco products for health and Permenkes No.56 / 2017 concerning pictorial health warnings. Since this Minister of Health Regulation came into force, almost all cigarette packages have health warnings with pictures. Although not all cigarettes have health warnings in their implementation (such as small and home cigarette producers), this effort should be appreciated because it is not easy to issue pro-tobacco control policies in this country. Also, the effectiveness of health warnings is still under the further study of its effects on Indonesian society.

For achievements in the non-smoking area, Indonesia has succeeded in increasing the number of cities and regencies that have no-smoking zones. The same thing happened in its application, namely the number of schools implementing the KTR also increased. From the original target of only $40 \%$ of cities with KTR, the realization that occurred exceeded the goal, which was $42.4 \%$. A total of 218 districts/cities out of 514 districts/cities have KTR regulations and have successfully implemented them in $50 \%$ of schools in their respective regions. So that the achievement of cities/regencies with KTR achieved by Indonesia in 2018 amounted to $106 \%$.

Until 2018 there were 340 districts/cities $(67.5 \%)$ that had regulations on nosmoking zones. Among them are 200 districts/cities (38.9\%) in the form of NonSmoking Regional Regulations and 127 regencies/cities (24.7\%) in the way of Regents or Mayor's regulations. There are still $174(33, \%)$ districts/cities either that do not yet have rules or are still in the form of circulars and decrees.

Of the various achievements, the authors see that tobacco control efforts in Indonesia are quite reasonable. By not denying that there are still shortcomings and the implementation has not gotten maximized, Indonesia's efforts still need to be appreciated. Most policies have an impact on the micro, even personal. The community can already feel the effect of the implementation of KTR, especially in big cities that are concerned about public health issues. Besides the excise tax policy also affects household needs, the price of cigarettes that increases effectively can reduce the amount of cigarette consumption so that it can control other consumption needs, as the authors explained in the previous chapter. 


\section{Conclusions and Suggestions}

\subsection{Conclusions}

Tobacco control is all forms of effort to reduce consumption, production, and distribution of tobacco products. Protecting current and future generations from the tobacco pandemic, the rules are focused so that cigarettes cannot get reached by young people, both preventive and curative. At present, Indonesia faces a situation where the number of young smokers is increasing every year. This problem certainly poses a threat to Indonesia, which is in the midst of a sustainable development process.

Tobacco control got done because cigarettes as tobacco products are goods whose use needs to be monitored and restricted. After all, it causes health problems. An increase in the number of young smokers in Indonesia will be a threat to human resources in the future. Thus, issues related to cigarettes require special efforts that get carried out collaboratively if stakeholders are involved.

Tobacco control efforts in Indonesia get carried out under the mandate of the 2015-2019 RPJMN development target, which is to reduce the prevalence of child smokers to 5.4\% during the first period of President Joko Widodo's administration. Some things that Indonesia does include. Namely, (1) Excise Regulation, increasing cigarette excise periodically every year, thereby affecting the price of cigarettes to protect vulnerable groups, (2) Enforcement of No-Smoking Areas, the implementation of this policy is mandated by Presidential Regulation No. 109/2012. lahira various systems in the form of regional regulations, mayor regulations, and regent regulations that prohibit cigarette consumers in seven public open spaces, (3) Pictorial Health Warning, effectively came into effect in 2017 and applied by almost the entire cigarette industry. (4) blocking adverts and promotions on cigarettes on the Internet. These various efforts were carried out by all technical ministries, namely the finance ministry, the health ministry, the communication and information ministry in coordination with the National Development Planning Agency / Bappenas.

This research finally explains that Indonesia is proven to have made efforts to control tobacco to achieve the national target of reducing the prevalence of child smokers. The efforts made are quite significant compared to previous years. This argument could get viewed by many things. Namely, the increase in the number of cities and regencies that already have local regulations on non-smoking areas. The price of cigarettes that are increasingly expensive so that children cannot reach them, health warnings that include disturbing images on cigarette packs, and also advertisements and promotions for cigarette products that no longer found on the Internet.

Although, in reality, this effort is certainly not yet optimal, appreciation should get given to the Indonesian government in controlling tobacco. Contro with goods whose producers contribute excise in the number of trillions of rupiah each year is certainly not easy. There are so many challenges and faces, especially when dealing with the private sector, the Cigarette industry. The tug-of-war of interests, ego-sectoral, is a certainty in the constellation of tobacco control policies in Indonesia. Indonesia needs support from various parties, both the community, NGOs, technical guidance from the SDGs to strengthen the implementation of a comprehensive and comprehensive tobacco control framework, by target 3.a of the goal of sustainable development. 
The participation of all the ministries and technical institutions involved in tobacco control is essential to develop. So it can be concluded that efforts to control Indonesian tobacco in achieving target 3.a already exist and have a policy framework. The implementation of the policy already exists, but it is not yet optimal. Again, this effort requires collaboration and cannot be done unilaterally by one or two institutions. Tobacco control is a very complex program because it is very closely related to sustainable human development.

\subsection{Recommendations}

Based on the explanation that the author has described, suggestions by this study are as follows:

1. For the government, there needs to be a revision of PP 109 of 2012, especially in the No Smoking Area point, to cover all public facilities. Also, it is necessary to have a policy related to plain packaging on cigarette packaging, as has been imposed by countries that have ratified the FCTC. The focus of revision PP $109 / 2012$, if possible, is to contain FCTC points so that Indonesia can implement the contents of the tobacco control framework without accessing its policies.

2. For the Technical Ministries, such as the finance ministries to continue to increase excise regularly and to simplify tiers. While the department of health needs to educate the public more intensely, primarily related to the implementation of KTR, the prohibition of underage sales, and cigarette advertisements, one platform that can get used is the healthy community movement program. Collaboration and coordination related to tobacco control efforts also need to be done routinely and periodically, so that the policies issued are in line with the goals of sustainable development.

3. For non-governmental organizations, it is advisable to advocate for the implementation of tobacco control continually. Also, Indonesia still has a few academic references related to the impact of cigarette consumptioEconomye economy and psycho-social. If possible, research institutions that focus on the issue of tobacco control to make scholarly contributions in the form of policy papers and research in advocacy. 


\section{BIBLIOGRAPHY}

\section{Books}

Anderson, J. E. (1984). Public Policy Making. Holt Rinehart \& Winston.

DeMenno, M. B. (2018). The Politics of the RePolicy-makingicymaking Process:

Three Essays on Governments, New York: the Sanford School of Public Policy.

Evera, S. v., (1997). A Guide to methods for students of political science. London:

Cornell University Press.

Gerston, L. N. (2002). Public Policy Making in a Democratic Society: A Gude to chivic Engagement. California.

Petchko, K. (2018). How to Write About Economics and Public Policy. EBSCO

Publishing. PKJS UI. (2019). Pemetaan Pengendalian Tembakau. Depok:

Universitas Indonesia.The Tobacco Atlas. (2015). The Fifth Edition. Tobacco

Atlas.

\section{Documents}

Peraturan Presiden No. 57. (2017). Pelaksanaan Tujuan Pembangunan Berkelanjutan. DKI Jakarta: Presdien RI.

Peraturan Presiden. (2010). Peraturan Presiden No. 42 Tahun 2010. Jakarta: Indonesia.

\section{Journals}

Klarin, T. (2018). The Concept of Sustainable Development:. Zagreb International Review of Economics \& Business, Vol. 21, No. 1, 67-94.

\section{Reports}

Center for Indonesia Sustainable Development Initiatives. (2019). Kebijakan Pengendalian Tembakau di Indonesia. Jakarta: CISDI.

Direktorat P2PTM. (2018). Laporan Kinerja Direktorat P2PTM Kementerian Kesehatan

Kesehatan RI.

DKI Jakarta: Kementerian

WHO. (2008). FCTC. Jenewa: WHO.

WHO. (2019). Stunting in a nutshell. Geneva: WHO International.

\section{Interview}

Nova. (2019). Interview. Direktorat KGM Bappenas. Jakarta.

Rizka, L. (2019, November 6). Interview. Kebijakan Pengendalian Tembakau di Indonesia. (G. D. Hapsari,) 
Sandra, T. (2019). Interview. Direktorat P2TM Kementerian Kesehatan. Jakarta.

\section{Website}

ACOSS. (2016). Poverty in Australia in 2016. dhttp://www.acoss.org.au/wpcontent/uploads/2016/10/Poverty-in-Australia-2016.pdf

Bappenas RI. (2015). RPJMN. Jakarta: Bappenas RI.

BPPK Kemenkes RI. (2018). Riset Kesehatan Dasar

https://www.cancerwa.asn.au/articles/news-2016-media-releases/how-does-tobaccosmoking-contribute-to-poverty/

Encyclopedia Britannica. (2016, May 23). Governance. www.britannica.com/topic/governance

Khamdi, M. (2013). Kemenperin Tolak Ratifikasi FCTC.

https://kemenperin.go.id/artikel/8275/Kemenperin- Tolak-Ratifikasi-FCTC

Noya, A. B. (2018, April 2). Memahami Epidemologi dan Istilah-istilahnya. www.alodokter.com/memahami-epidemiologi-dan-istilah- istilahnya

Raharjo, D. B., \& Tanjung, E. (2019, Desember 13). Intervensi Industri Rokok ke Dalam RUU Pertembakauan? https://www.suara.com/news/2018/12/13/110409/intervensiindustri-rokok-ke-dalam-ruu-pertembakauan?page=all

Sorikmas Mining. (2012, June 12). PT. Sorikmas Mining. https://www.sorikmas.co.id/2012/06/12/konsep-dasar-pembangunan-berkelanjutan/

TCSC. (2012, Agustus). FCTC. http://tcsc- indonesia.org/wpcontent/uploads/2012/08/FCTC.pdf

The Stroke Association. (2017, September). Smoking and The Risk of Sroke. www.google.com/url?sa=t\&source=web\&rct=j\&url=https://www.stroke.org.uk/sites/ default/files/smoking_and_the_risk_of_stroke.pdf\&ved=2ahUKEwi_psCVutjlAhW

VeisKHcnFBqsQFjAKegQIAxAB\&usg=AOvVaw0E7ydSLOrg7h42hIKxmlTh 